\title{
Hydrological Change Effects on Sungai Langat Water Quality
}

(Kesan Perubahan Hidrologi ke atas Kualiti Air Sungai Langat)

\author{
Marina Zainal Abidin, AhMAD Abas KUTTY*, TUKimat LiHAn \& NURUl AKHMA ZaKaria
}

\section{ABSTRACT}

This study attempts to assess the impact of various types of land use along Sungai Langat and describes hydrological change and water quality variation along this river. This study also determines water quality of Sungai Langat based on low flow dry period $Q_{100,7}$ using the application of $Q U A L 2 K$. Dissolved oxygen (DO), $\mathrm{pH}$, temperature and conductivity were measured in situ. Biochemical oxygen demand $\left(\mathrm{BOD}_{5}\right)$, ammonia nitrogen $\left(\mathrm{NH}_{3}-\mathrm{N}\right)$ and total suspended solid (TSS) were analysed according to the standard methods (APHA). Water quality data was referred to National Water Quality Standards for Malaysia (NWQS) proposed by Malaysian Department of Environment (DOE) to estimate Sungai Langat water quality status. Four important water quality parameters namely $\mathrm{DO}, \mathrm{BOD} \mathrm{D}_{5} \mathrm{NH}_{3}-\mathrm{N}$ and TSS were simulated with QUAL2K version 2.07 for $83.67 \mathrm{~km}$. As regard to individual parameter, DO classified this river into class III, BOD in Class II, $\mathrm{NH}_{3}-\mathrm{N}$ in Class IV and TSS in Class I. Based on QUAL2K simulation for low flow scenario, the results clearly demonstrates a gradually reduction of DO and $\mathrm{BOD}_{5}$ whereas $\mathrm{NH}_{3}-\mathrm{N}$ and TSS display opposite. Only $\mathrm{NH}_{3}-\mathrm{N}$ was found significantly increase which cause low water quality class towards the downstream. Three parameters namely $D O, B O D_{5}$ and $\mathrm{NH}_{3}-\mathrm{N}$ show effects of industrial which approximately located at the middle of river stretch. The TSS was contributed to the river system at the upstream and downstream of the river stretch which most likely from sand mining activity which located at Sungai Long, Cheras (near R5) and Sungai Semenyih (R11).

Keywords: Modelling; QUAL2K; Sungai Langat; water quality

\section{ABSTRAK}

Kajian ini cuba menilai kesan pelbagai jenis guna tanah di sepanjang Sungai Langat dan menerangkan perubahan hidrologi dan variasi kualiti air di sepanjang sungai ini. Kajian ini juga menentukan kualiti air Sungai Langat berdasarkan aliran musim kering $Q_{100,7}$ dengan menggunakan pemodelan kualiti air QUAL2K. Oksigen terlarut (DO), pH, suhu dan kekonduksian diukur secara in situ. Permintaan oksigen biokimia $\left(\mathrm{BOD}_{5}\right)$, nitrogen ammonia $\left(\mathrm{NH}_{3}-\mathrm{N}\right)$ dan jumlah pepejal terampai (TSS) telah dianalisis di makmal mengikut kaedah piawai (APHA). Data kualiti air dirujuk kepada Piawaian Kualiti Air Negara (NWQS) yang dicadangkan oleh Jabatan Alam Sekitar Malaysia (JAS) untuk menganggarkan status kualiti air Sungai Langat. Empat parameter kualiti air penting iaitu $\mathrm{DO}, \mathrm{BOD}_{5} \mathrm{NH}_{3}-\mathrm{N}$ dan TSS disimulasi dengan menggunakan QUAL2K versi 2.07 bagi $83.67 \mathrm{~km}$. Berdasarkan parameter individu, Do berada pada Kelas III, BOD dalam Kelas II, $\mathrm{NH}_{3}-\mathrm{N}$ pada Kelas IV dan TSS pada Kelas I. Berdasarkan simulasi QUAL2K untuk senario aliran rendah, keputusan jelas menunjukkan penurunan secara beransur-ansur bagi DO dan $\mathrm{BOD}_{5}$ manakala $\mathrm{NH}_{3}-\mathrm{N}$ dan TSS menunjukkan sebaliknya. Hanya $\mathrm{NH}_{3}-\mathrm{N}$ didapati meningkat dengan ketara yang menyebabkan kelas kualiti air menurun ke hilir sungai. Tiga parameter iaitu $\mathrm{DO}, \mathrm{BOD}_{5}$ dan $\mathrm{NH}_{3}-\mathrm{N}$ menunjukkan kesan perindustrian yang terletak berhampiran jajaran tengah sungai. TSS disumbangkan kepada sistem sungai di hulu dan hilir yang berkemungkinan besar berpunca daripada aktiviti perlombongan pasir yang terletak di Sungai Long, Cheras (berhampiran R5) dan Sungai Semenyih (R11).

Kata kunci: Kualiti air; pemodelan; QUAL2K; Sungai Langat

\section{INTRODUCTION}

Sungai Langat is one of the significant river in Selangor that serves as water supply for 16 water intake points within Sungai Langat Basin (LUAS 2011). There is a total of 10 Water Treatment Plants (WTP) in Sungai Langat Basin (LUAS 2015) that supplies for Putrajaya, Sepang, Kajang and Kuala Langat. It also supplies water to the other areas such as Federal Teritory of Kuala Lumpur, Shah Alam, Klang, Petaling Jaya, Keramat, Wangsa Maju and Kelang Lama (LUAS 2011). The water supplies cater for domestic usage, commercial activities, agricultural and industrial demand.
This river flows through various types of land use such as residential, industrial, town and agriculture. Based on land use data obtained by the Department of Agriculture (2015), 47\% of the land use activity along the $1 \mathrm{~km}$ buffer of Sungai Langat is dominated by commercial grown crops which includes palm oil and rubber plantation $\left(183 \mathrm{~km}^{2}\right)$, observed mainly at the downstream of Sungai Langat basin. $17 \%$ or $66 \mathrm{~km}^{2}$ of the land use is dominated by municipal, residential and other physical developments which mainly located at the middle stretch of the river. Third major land use around the Sungai Langat locality is dominated 
by mixed plantation which includes orchards, banana, coconuts and other fruit trees for local consumptions and sales $(10 \%)$. Mixed plantations are located mainly in the upstream and middle stretch of the river basin. A total area of $4.35 \mathrm{~km}^{2}$ along Sungai Langat is used for quarry and mining activities. Other than that, around $0.6 \%$ of the Sungai Langat areas are utilised for recreational purposes located mostly at the upper stream Sungai Langat.

As regard to land use, the large areas used for growing palm oil and rubber plantation would become the root of water quality problem if not properly managed. Excessive nutrient inputs from fertilising can result in runoffs to the river and become the major non-point source contamination. Nitrogen, phosphorus and potassium are the major components of fertilisers which could lead to eutrophication (LUAS 2015). High nutrient content in the river can reduce DO in the waterway and in turn deplete the water quality. LUAS (2015) also reported that, domestic and industrial discharge which mostly released at middle river stretch contains discharges that vary from industry to industry. Common industrial effluent includes heavy metals, ammonia, BOD and chemical oxygen demand (COD).

In Sungai Langat Basin, sand dredging activities in Sungai Langat are one of the state revenue activities that have directly impacted the Sungai Langat water quality. At the middle of Sungai Langat basin, a sand mining area was observed at Sungai Long (R5) and another one located at Sungai Semenyih (R11). LUAS (2015) reported that, based on 2013 records, a total of 30 sand mining locations were in operation in the basin, which six are land sand mining and the other 24 are river sand mining. Sand mining activity has long been identified as an important source of TSS, turbidity and sedimentation. High TSS intrusion into the river system worsen the river water quality specifically during heavy rainfalls. The unmitigated effect of sand mining can pollute the river further downstream and can destroy aquatic flora and fauna inhabiting the river.

Sungai Langat basin is the main domestic water supply for locals, but has been identified being polluted with various types of contaminants. In 1999, 42\% of Sungai Langat basin was contaminated with suspended solids (SS) due to improper planning and vigorous land clearing activities (Juahir et al. 2011). Similar author also reported that the $\mathrm{BOD}_{5}$ was increased up to $30 \%$ and $\mathrm{NH}_{3}-\mathrm{N}$ was $28 \%$ which contributed by industrial discharge and animal husbandry and domestic sewage, respectively. Rapid developments along the riverbank and extensive of land use change have significantly degraded Sungai Langat water quality. Modification of land surface during urbanization typically will increase the impervious surfaces with addition of roofs and roads, construction of drainage systems, soil compactions and modifications to vegetation cover (Yang et al. 2011).

Studies have indicated that urbanization has greatly affected hydrology of an area by changing groundwater recharge and discharge. Under normal hydrologic regime, the groundwater discharges are able to sustain flows in stream and rivers during dry period (Yang et al. 2011). Zhang and Schilling (2006), indicated that perennial vegetation conversion to seasonal row crops and agricultural activities along Mississippi River (MR) basin since 1940 have decreased evapotranspiration and surface runoff and in turn increased groundwater recharge, base flow and stream flow. However, for the catchment that was converted into urban, low flow have the tendency for further reduction due to the effects of direct runoffs, infiltration and higher evapotranspiration as a result of higher urban impervious surfaces (Simmons \& Reynolds 1982). Othman (2007) in his study indicated that, one of the factor that always relates to disturbance of water supply incidences is the decrease of water resources. The same author added that, decrease in water resources may be a consequence of land use change within the catchment particularly involving the forest exploitation into agricultural and urbanization.

The recent years have seen frequent WTP shutdown incidents in Langat basin during the low flow period particularly due to exceedance of ammonia levels (LUAS 2015). Based on the same report, three cases of WTP shutdowns due to high ammonia was recorded in 2009 , once in Cheras Mile 11 WTP and two times in Salak Tinggi WTP. All the three cases were recorded during the dry period between June and July. Absence of rain during the dry period in Cheras intake had caused little chance of diluting the potent concentration of ammonia (Krishnan 2009).

The source of contamination at Salak Tinggi WTP has been identified as industrial waste from Nilai Industrial Area dumped into Sungai Nilai, which merges with Sungai Labu, the water intake point for Salak Tinggi WTP (Krishnan 2009). The incidents had caused minimal disruptions to about 10,000 consumers in 19 villages which benefits from Salak Tinggi WTP (Anon 2009a). At the end of October 2009 (Anon 2009b) reported that the Salak Tinggi WTP was closed for the fourth time due to ammonia contamination.

In 2010, another similar case of ammonia pollution during the low flow was recorded. LUAS (2015) and Puncak Niaga (2014) has identified the probable source of contamination came from effluent discharged from the upstream industrial area. Subsequently, in 2011, 2012 and 2013, seven more cases of WTP shutdown incidents reported due to diesel spillage and odour. Subsequently, in February 2014, Choong (2014) reported another two WTP shutdown incidents occurred due to ammonia contamination at the raw water intake that supplies for residents in Hulu Langat and Kuala Langat. According to Rajendra et al. (2016), Sungai Langat is reported contaminated with higher pollution level during low flow as compared to the normal flow period. As a result, the incident has again turned to a domestic water supply disruption. A total of 16 river pollution cases in Selangor was reported until October 2016, which eight cases are in Sungai Langat. This caused disruption of water treatment plant (WTP) and affected more than a million users in Hulu Langat, Kuala Langat, Petaling Jaya and Sepang districts. 
From 16 pollution cases above, four occasions occurred at Sungai Langat treatment plant which was due to excessive ammonia level during dry season (Rajendra et al. 2016). LUAS (2015) affirmed that, although these cases have occurred quite a number of times in the past, it should not be treated as a common issue.

Local authorities, academicians, consultants and stakeholders in Malaysia have gradually begun implementing the use of water quality modelling as a critical management tool for river basins conservation and rehabilitation (Zainudin \& Mohamed 2006; Zainudin et al. 2008). The water quality model assessed the probability of scenarios that demonstrates the effects of any changes implemented along the river on river water quality parameters. Several countries, such as Spain, the United States, Slovenia, South Korea and China have applied water quality predictive models in their water managements. Several modifications have been incorporated into the model to perfectly fit the actual river condition and enabling accurate data simulation (Cubillo et al. 1992; Drolc \& Končan 1996; Little \& Williams 1992; Song \& Kim 2009; Walton \& Webb 1994; Zhang et al. 2012). In addition, the application of QUAL2E was efficaciously applied to assess the pollution prevention program of the Kao-Ping River Basin in Taiwan (Ning et al. 2001). The QUAL2K is a United States Environmental Protection Agency (US EPA) approved model used to determine waste load allocations (WLA) and total maximum daily load (TMDL) (Neilson et al. 2012). The QUAL2K is an updated version of QUAL2E for a unidirectional, steady state numerical model which stimulates flow, temperature and water quality along river reach (Chapra et al. 2008). In order to determine the fate of selected water quality parameters in Sungai Langat water body, QUAL2K was employed as a tool. Simulation of the QUAL2K describes the concentration of each contaminant due to the receiving river and its tributaries, which is based on the hydro geometry characteristics. The simulation of Sungai Langat water via QUAL2K on existing condition low flow scenario is capable to demonstrate the magnitude of impact. The low flow scenario based on $\mathrm{Q}_{100,7}$ values are referred from Sungai Langat Basin Management Plan (2015-2020) by Selangor Waters Management Authority, (LUAS 2015) and further derived from National Water Resources Study (NRWS) (2000-2050) and Formulation of National Water Resources Policy (Department of Irrigation \& Drainage 2011).

Sungai Langat as an important source of water supply is showing sign of stress with the current various land use activities along the river. River pollution during dry period has caused shutdown incidents of WTP. Therefore, it is crucial to understand the effects of land use activities on water quality parameter especially during dry period. The objectives of this study include: to assess the impact of various types of land use along Sungai Langat; describes hydrological change and water quality variation along this river; and determines water quality of Sungai Langat based on low flow dry period $\mathrm{Q}_{100,7}$ where the dilution capacity is expected to be the lowest.

\section{MATERIALS AND METHODS}

Monthly mean flow rate $\left(\mathrm{m}^{3} / \mathrm{s}\right)$, monthly rainfall precipitation $(\mathrm{mm})$ and monthly rain days data were used as references to determine the sampling month with the highest monthly mean flow rate in the wet season. Consequently, hydro geometry and water quality data of November 2016 which was taken from major tributaries of Sungai Langat catchment was used. The water quality data was later compared to NWQS to determine its status. Prior to determination of the baseline data, a simulation of low flow scenario $\mathrm{Q}_{7,100}$ was conducted with QUAL2K. The water quality of Sungai Langat based on the low flow simulation $\mathrm{Q}_{7,100}$ was assessed and the impact of land use activities observed along the river were evaluated. The details of the method were described in this study.

\section{SAMPLING AND STUDY AREA}

Surveys and samplings were conducted on November 2016 along Sungai Langat stretch and tributaries which located in Selangor, Peninsular Malaysia. Climate of Sungai Langat catchment is equatorial (hot and humid) throughout the year, with unvarying temperatures, high humidity and rainfall. The hydrological characteristics of the study area are further described in this section.

Yang et al. (2011) had conducted a descriptive analysis on monthly mean flow rate $\left(\mathrm{m}^{3} / \mathrm{s}\right)$ on Department of Drainage and Irrigation (DID) gauging stations at Kampung Lui (upstream of Langat basin) and Dengkil (downstream of Langat basin). Total daily flow rate data of 35 years from 1972 to 2009 data at Lui sub and 44 years flow rate data (1965 to 2009) at Dengkil sub basin were analysed. The overall result showed that the lowest monthly mean flow rate occurred in February and August. November was recorded with highest monthly mean flow rate compared to other months.

The meteorological stations selected for this study are Ampangan Air Semenyih and PORIM Bangi. A total of 20 years rainfall measurements was obtained from the Malaysian Meteorological Department (2017). The locations of the meteorological stations are illustrated in Figure 1(a). The average monthly rainfall and number of rain days are given in Figures 2 and 3. The upstream area begins at Hulu Langat and flows to Kuala Selangor at the downstream before it drains into the Straits of Malacca. The total catchment area of Sungai Langat is approximately $1,815 \mathrm{~km}^{2}$ (Juahir et al. 2011) and has several tributaries with the major ones being Sungai Lui, Sungai Semenyih and Sungai Labu. Moreover, there are two dams located in the basin which are the Langat Dam with catchment area of $54 \mathrm{~km}^{2}$ and the Semenyih dam with catchment area of $41 \mathrm{~km}^{2}$. The dams and selected sampling stations are showcased in Figure 1(a).

Purposive sampling had been conducted with 14 pre-determined rivers reach to represent zones of land use along the river watershed and in the wettest month of the year. Based on data obtained from MET, November has the highest record of rainfall at both meteorological 
stations throughout the year for 20 years. PORIM Bangi Meteorological Station recorded an average of $379.4 \mathrm{~mm}$ and Ampangan Air Semenyih with $348.5 \mathrm{~mm}$ from year 1997-2016. Figure 2 shows 20 years average monthly rainfall (mm) at PORIM Bangi and Ampangan Air Semenyih Meteorological Station (1997-2016). The month of November similarly have the highest number of raindays with 19 days in PORIM Bangi station and 23 rain days at Ampangan Semenyih meteorological stations. Figure 3 describes average monthly raindays at PORIM Bangi and Ampangan Air Semenyih Meteorological Station for 20 years (1997-2016). In both of the long-recorded data, November has the highest average monthly rainfall with regard to precipitation and number of rain days. Although the single sampling data of water quality in November 2016 is statistically insufficient to be deemed as highest flow, it does essentially make an appropriate representation with regard to highest monthly mean flow rate $\left(\mathrm{m}^{3} / \mathrm{s}\right)$ in 35 and 44 years data and highest average monthly rainfall precipitation $(\mathrm{mm})$ together with highest number of rain days in 20 years recorded in Langat sub basin. The sampling locations also demonstrates fairly good representation of the major tributaries in the river watershed. Therefore, a purposive sampling to represent the month with highest flow is represented in this study.

\section{WATER QUALITY AND QUAL2K SIMULATION}

Hydro geometry measurements and water samplings were conducted and evaluated throughout the 14 pre-determined reaches (Figure $1(\mathrm{~b}))$. The parameters of DO $(\mathrm{mg} / \mathrm{L}), \mathrm{pH}$, temperature $\left({ }^{\circ} \mathrm{C}\right)$ and conductivity $(\mu \mathrm{S} / \mathrm{cm})$ were measured using YSI Professional Series Plus model. Other parameters namely $\mathrm{BOD}_{5}, \mathrm{NH}_{3}-\mathrm{N}$ and TSS were analysed in laboratory according to standard method (APHA 1998). Triplicates of water sample were taken from each station and transported to the laboratory under temperature of $\leq 4^{\circ} \mathrm{C}$. The $\mathrm{BOD}_{5}$ was measured using five days incubation method and $\mathrm{NH}_{3}-\mathrm{N}$ was analysed using Nessler's Method (HACH 2003). As for the TSS, it was measured via gravimetric procedure. The acquired water parameter data was analysed for NWQS as stipulated by the DOE. The data gathered during the survey and sampling for hydrological and water quality are summarized in Table 1.

Sungai Langat delineation is divided into 14 reaches according to the characteristics of the river. Each reach is labelled according to the order which starts at the upstream ( $\mathrm{km} \mathrm{83.67)} \mathrm{and} \mathrm{end} \mathrm{point} \mathrm{simulation} \mathrm{distance} \mathrm{at} \mathrm{km} 0.00$ (Table 2). A set of data for water quality parameters comprises of data taken in November 2016 is compared with river discharge $\left(\mathrm{m}^{3} / \mathrm{s}\right)$ data taken in November 2016 and low flow analysis $Q_{7,100}$ values. These values are based on the Q/MAM ratio of 0.445 , as formulated in NWRS (20002050) (Department of Irrigation \& Drainage 2011). The simulation of Sungai Langat water quality was performed via QUAL2K to produce a water quality model. Four (4) selected water quality parameters i.e. $\mathrm{BOD}_{5}, \mathrm{DO}, \mathrm{NH}_{3}-\mathrm{N}$ and TSS were simulated to produce ambient and low flow scenario of $\mathrm{Q}_{7,100}$.

The calibration of QUAL2K model was made with water quality data and hydrological data so as to ensure the model represent the river in the most accurate manner. During calibration, the hydrological characteristics were figured in order to gain an agreement between the observed and simulated data. The hydraulic variables for calibrations of flow and velocity were carried out adhering the following procedures:

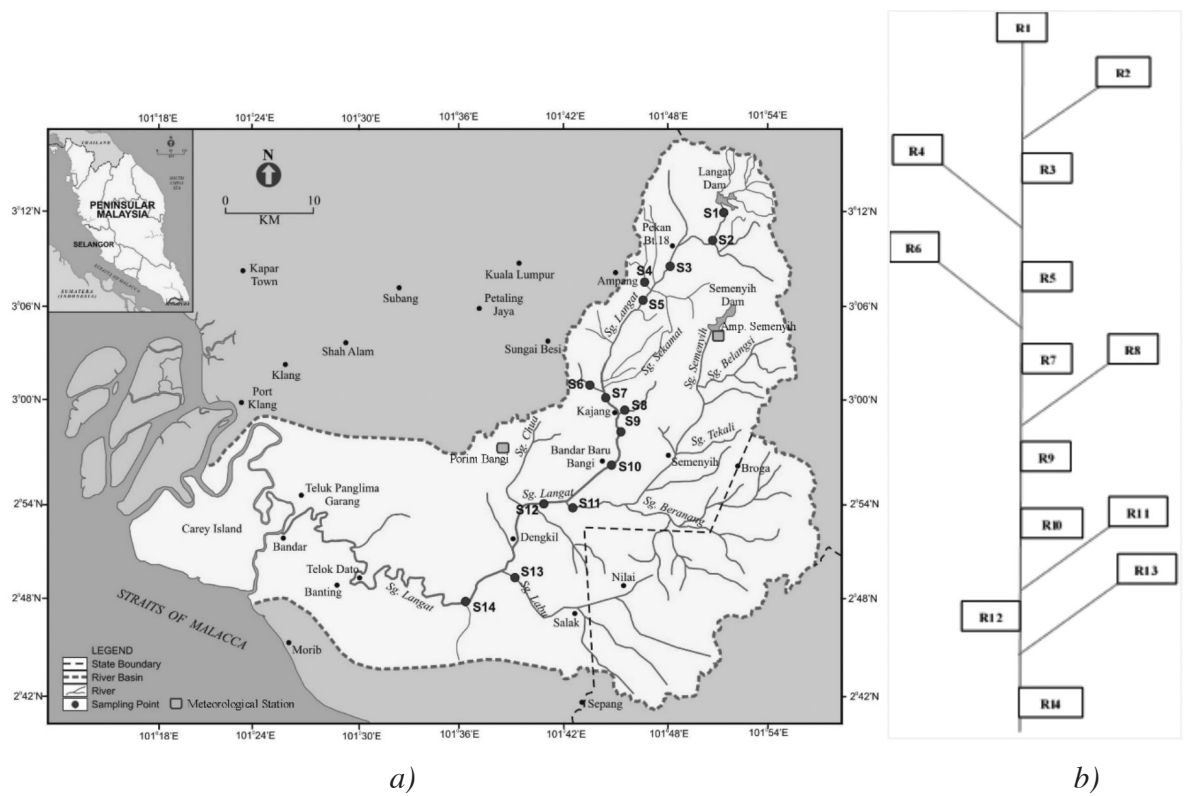

FIGURE 1. a) Water quality and meteorological stations located along Sungai Langat

b) Delineation of Sungai Langat 
Rainfall Pattern (1997-2016)

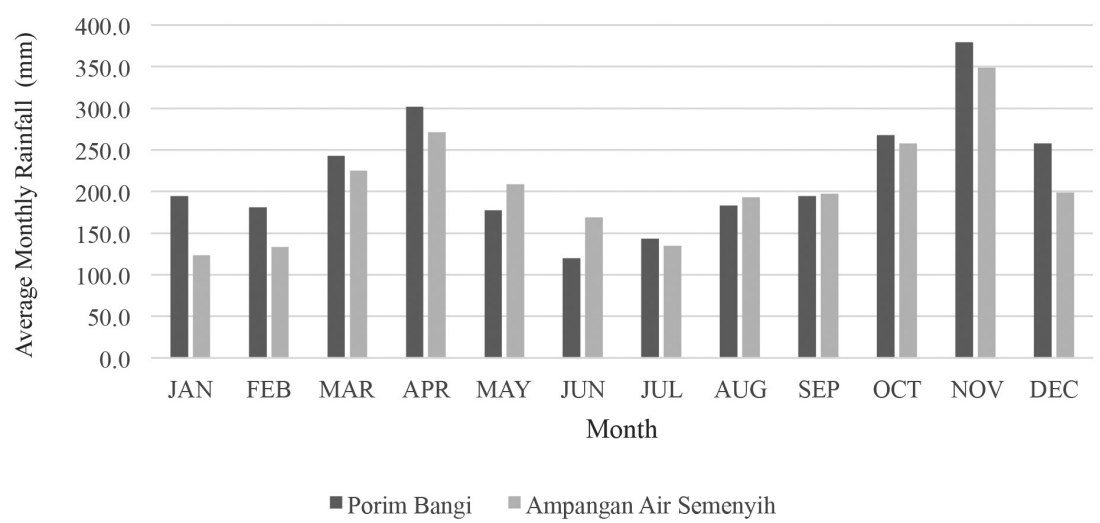

FIGURE 2. 20 years average monthly rainfall (mm) at PORIM Bangi and Ampangan Air Semenyih Meteorological Station (1997-2016)

TABLE 1 . Water quality and hydraulic measurements of Sungai Langat and tributaries

\begin{tabular}{lccccccccc}
\hline $\begin{array}{l}\text { Reach/ } \\
\text { Parameter }\end{array}$ & $\begin{array}{c}\mathrm{DO} \\
(\mathrm{mg} / \mathrm{L})\end{array}$ & $\begin{array}{c}\mathrm{BOD}_{5} \\
(\mathrm{mg} / \mathrm{L})\end{array}$ & $\begin{array}{c}\mathrm{TSS} \\
(\mathrm{mg} / \mathrm{L})\end{array}$ & $\begin{array}{c}\mathrm{NH}_{3}-\mathrm{N} \\
(\mathrm{mg} / \mathrm{L})\end{array}$ & $\begin{array}{c}\text { Conductivity } \\
(\mu \mathrm{S} / \mathrm{cm})\end{array}$ & $\begin{array}{c}\text { Width } \\
(\mathrm{m})\end{array}$ & $\begin{array}{c}\text { Depth } \\
(\mathrm{m})\end{array}$ & $\begin{array}{c}\text { Flow } \\
(\mathrm{m} / \mathrm{s})\end{array}$ & $\begin{array}{c}\text { Discharge } \\
\left(\mathrm{m}^{3} / \mathrm{s}\right)\end{array}$ \\
\hline R1 $(\mathrm{H})$ & 5.68 & 2.86 & 2.20 & 0.64 & 187.23 & 11 & 0.69 & 0.21 & 1.49 \\
R2 $(\mathrm{H})$ & 5.27 & 1.52 & 2.30 & 0.02 & 178.53 & 11 & 0.45 & 0.35 & 1.58 \\
R3 & 4.05 & 3.00 & 12.23 & 0.66 & 193.27 & 11 & 0.51 & 0.20 & 1.28 \\
R4 $(\mathrm{H})$ & 4.47 & 0.65 & 2.30 & 0.04 & 175.70 & 5 & 0.67 & 0.14 & 0.43 \\
R5 & 3.94 & 1.51 & 10.37 & 0.15 & 181.13 & 18 & 2.01 & 0.29 & 9.94 \\
R6 $(\mathrm{H})$ & 1.72 & 11.00 & 2.63 & 4.89 & 421.17 & 22 & 0.78 & 0.08 & 1.37 \\
R7 & 2.15 & 6.50 & 14.87 & 4.22 & 383.43 & 18 & 0.60 & 0.54 & 5.67 \\
R8 $(\mathrm{H})$ & 1.35 & 5.32 & 10.43 & 2.85 & 384.13 & 13 & 0.47 & 0.17 & 0.96 \\
R9 & 1.63 & 3.68 & 10.83 & 2.69 & 392.17 & 27 & 1.43 & 0.35 & 12.94 \\
R10 & 0.72 & 7.14 & 5.43 & 3.37 & 407.80 & 26 & 1.49 & 0.20 & 7.59 \\
R11 $(\mathrm{H})$ & 6.36 & 2.23 & 21.27 & 1.72 & 260.50 & 33 & 4.60 & 0.14 & 20.59 \\
R12 & 1.88 & 2.21 & 13.60 & 2.85 & 298.33 & 33 & 4.23 & 0.26 & 34.65 \\
R13 $(\mathrm{H})$ & 2.95 & 2.86 & 16.73 & 1.38 & 228.23 & 17 & 0.80 & 0.27 & 3.52 \\
R14 & 4.43 & 1.14 & 20.03 & 2.32 & 324.80 & 48 & 3.80 & 0.09 & 15.90 \\
\hline
\end{tabular}

Flow $\left(\mathrm{m}^{3} / \mathrm{s}\right)$ The non-point sources and withdrawals are modelled as line sources. Any non-point source or withdrawals is defined by its initial volumetric flow and finish $\mathrm{km}$ points volumetric flow. Mean flow for the reach was used and the difference between downstream flow and upstream flow was measured as a diffused source. The flow was then distributed to or from each element in a lengthweighted manner. A steady-state flow is implemented for each model element in QUAL2K as (1):

$$
\mathrm{Q}_{\mathrm{i}}=\mathrm{Q}_{\mathrm{i}-1}+\mathrm{Q}_{\mathrm{in}, \mathrm{i}}-\mathrm{Q}_{\mathrm{out}, \mathrm{i}}
$$

where $\mathrm{Q}_{\mathrm{i}}$ is the outflow from element $i$ into the downstream element $\mathrm{i}+1\left(\mathrm{~m}^{3} \mathrm{~d}^{-1}\right) ; \mathrm{Q}_{\mathrm{i}-1}$ is the inflow from the upstream element $\mathrm{i}-1\left(\mathrm{~m}^{3} \mathrm{~d}^{-1}\right) ; \mathrm{Q}_{\mathrm{in}-1}$ is the total inflow into the element from point and nonpoint sources $\left(\mathrm{m}^{3} \mathrm{~d}^{-1}\right) ; \mathrm{Q}_{\text {out. } \mathrm{i}}$ is the total outflow from the element due to point and nonpoint withdrawals $\left(\mathrm{m}^{3} \mathrm{~d}^{-1}\right)$.

Velocity QUAL2K computes the depth and the velocity in one of three ways (Weirs, rating curves and Manning equations). Manning equation with regard to manning roughness coefficient and classification (Chow et al. 1998) was applied for simulation in this study. The reach mean velocity is used in the model and its calibration was carried out according to the river slope and $\mathrm{n}$ of Manning for natural river and streams. In steady state flow, the Manning equation expressed the association of flow and depth (2):

$$
\mathrm{Q}=\mathrm{S}_{0}^{1 / 2} / \mathrm{n} \times \mathrm{A}_{\mathrm{c}}^{5 / 3} / \mathrm{P}^{2 / 3}
$$

where $\mathrm{Q}$ is the flow $\left(\mathrm{m}^{3} \mathrm{~s}^{-1}\right) ; \mathrm{S}_{0}$ is the bottom slope $(\mathrm{m} / \mathrm{m})$; $\mathrm{n}$ is the Manning roughness coefficient; $\mathrm{A}_{\mathrm{c}}$ is the cross sectional area $\left(\mathrm{m}^{2}\right)$; and $\mathrm{P}$ is the wetted perimeter $(\mathrm{m})$.

The mathematical relationships that describes single reaction and concentrations of the water quality parameters modelled are described in the following paragraphs.

Dissolved oxygen increases due to plant photosynthesis. It is lost via fast CBOD oxidation, nitrification and plant respiration. Depending on whether the water is undersaturated or oversaturated it is gained or lost via reaeration (3) and (4): 
TABLE 2. Delineation of Sungai Langat

\begin{tabular}{llcc}
\hline \multirow{2}{*}{ Reach } & Reach Name & \multicolumn{2}{c}{ Distance $(\mathrm{km})$} \\
\cline { 3 - 4 } & & Upstream & Downstream \\
\hline R1 $(\mathrm{H})$ & Sungai Langat (Mainstem Headwater) & 83.67 & 74.58 \\
R2 $(\mathrm{H})$ & Sungai Lui (Headwater) & 1.82 & 0.00 \\
R3 & Sungai Langat & 74.58 & 67.69 \\
R4 $(\mathrm{H})$ & Sungai Semungkis (Headwater) & 4.76 & 0.00 \\
R5 & Sungai Langat & 67.69 & 52.42 \\
R6 $(\mathrm{H})$ & Sungai Balak (Headwater) & 7.82 & 0.00 \\
R7 & Sungai Langat & 52.42 & 36.64 \\
R8 $(\mathrm{H})$ & Kajang (Headwater) & 0.62 & 0.00 \\
R9 & Sungai Langat & 36.64 & 33.51 \\
R10 & Sungai Langat & 33.51 & 21.82 \\
R11 $(\mathrm{H})$ & Sungai Semenyih (Headwater) & 33.27 & 0.00 \\
R12 & Sungai Langat & 21.82 & 7.75 \\
R13 $(\mathrm{H})$ & Sungai Labu (Headwater) & 30.28 & 0.00 \\
R14 & Sungai Langat & 7.75 & 0.00 \\
\hline
\end{tabular}

$$
\begin{aligned}
S_{o}= & r_{o a} \text { PhytoPhoto }+r_{o d} \text { BotAlgPhoto }-r_{o c} \text { FastCOxid } \\
& -r_{o n} \text { NH4Nitr- } r_{o a} \text { PhytoResp- } r_{o d} \text { BotAlgResp } \\
& + \text { OxReaer }
\end{aligned}
$$

where

$$
\text { OxReaer }=k_{a}(T)\left(o_{s}(\text {,elev })-o\right.
$$

where $k_{a}(T)$ is the temperature-dependent oxygen reaeration coefficient [/d]; $o_{s}($ T,elev $)$ is the saturation concentration of oxygen $\left(\mathrm{mgO}_{2} / \mathrm{L}\right)$ at temperature, $\mathrm{T}$; and elevation above sea level, elev.

Fast reacting CBOD is gained via the dissolution of detritus and hydrolysis of slowly reacting CBOD. It is lost via oxidation and denitrification (5) and (6):

$$
\begin{aligned}
S_{c f}= & F_{f} r_{o d} \text { DetrDiss = SlowCHydr }- \text { FastCOxid } \\
& -r_{\text {ond }} \text { Denitr }
\end{aligned}
$$

where

$$
\text { FastCOxid }=F_{o x c} k_{d c}(T) c_{f}
$$

where $k_{d c}(T)$ is the temperature-dependent fast CBOD oxidation rate $[/ \mathrm{d}] ; F_{a x c}$ is the attenuation due to low oxygen [dimensionless]; $r_{\text {ondn }}$ is the ratio of oxygen equivalents lost per nitrate nitrogen that is denitrified; Denitr is the rate of denitrification $[\mu \mathrm{gN} / \mathrm{L} / \mathrm{d}]$.

The ammonia nitrogen increases due to organic nitrogen hydrolysis and phytoplankton respiration. It is lost via nitrification and plant photosynthesis (7):

$$
\begin{aligned}
S_{n a}= & \text { DONHydr+rnaPhytoResp-NH4Nitrif- } \\
& r_{n a} P_{a \mathrm{p}} \text { PhytoPhoto- } P_{a b} \text { BotAlgUptakeN }
\end{aligned}
$$

The ammonia nitrification rate is computed as (8):

$$
\text { NH4Nitrif }=F_{\text {oxna }} k_{n}(T) n_{a}
$$

where $k_{n}(T)$ is the temperature-dependent nitrification rate for ammonia nitrogen $[/ \mathrm{d}] ; F_{\text {oxna }}$ is the attenuation due to low oxygen (dimensionless).

The TSS are lost through settling (9) and (10)

$$
S_{m i}=- \text { InorgSettl }
$$

where

$$
\text { InorgSettl }=(v i / H) m i
$$

where $v i$ is the inorganic suspended solids settling velocity $[\mathrm{m} / \mathrm{d}]$.

QUAL2k model was calibrated using field measurements data. Hydraulic calibration was applied and roughness manning factor has been selected according to natural habitat. An acceptable match of the simulation and ground data was obtained. Correlation tests were undertaken to confirm appropriate agreement between calibration of simulation and ground data. A scenario of low flow $\mathrm{Q}_{7100}$ discharge $\left(\mathrm{m}^{3} / \mathrm{s}\right)$ was later applied to the model to estimate the fate of four parameters of water quality parameters during critical condition of low flow. Two scenarios of normal flow and low flow simulation output are presented on $\mathrm{DO}, \mathrm{BOD}_{5}$, TSS and $\mathrm{NH}_{3}-\mathrm{N}$ graphs (Figures 3 to 6).

\section{RESULTS AND DISCUSSION}

Results of the correlation test indicate that there is a positive correlation between observed data and simulated data except for $\mathrm{BOD}_{5}$. The calibrations conducted on water quality parameters also showed high percentage of agreement between observed and simulated data. The percentage of agreement for discharge, velocity, $\mathrm{DO}, \mathrm{BOD}_{5}$, $\mathrm{NH}_{3}-\mathrm{N}$ and TSS are $66 \%, 96 \%, 39 \%, 6 \%, 62 \%$ and $79 \%$, respectively. These prove that the hydrological and water quality parameters attained best agreement between the observed and simulated values. 
According to hydro geometric data, the discharge pattern increases as it flows to the mid-stream of Sungai Langat before it decreased again in the downstream. The low flow scenario showed that $\mathrm{Q}_{7,100}$ discharge simulation exhibited approximately 50\% discharge reduction along the river (Figure 4(a)). In addition, the velocity of the river increased towards the mid-stream of the river and then later decreased as it flows downstream (Figure 4(b)). The representation of the velocity appears accurate as the gradient in the upper stream is very steep and drops as it reaches the coastal plain. The low flow scenario demonstrates uniform reduction of velocity from the upstream to downstream as compared to the ambient.

The DO concentration of the baseline condition appeared to be in class II only at the upstream of the river and as it flowed downstream, it declined to Class III of NWQS (Figure 5). The DO decrease gradually as it flows through $\mathrm{km} 68$ as it was consumed by high input of $\mathrm{BOD}_{5}$ entered from R4 (Figure 6). However, the baseline DO concentration had managed to recover at $\mathrm{km} 21.82$ onwards after confluence with R11 (Sungai Semenyih) where a huge volumetric input $\left(20.59 \mathrm{~m}^{3} / \mathrm{s}\right)$ was introduced and dilution occurred. Nonetheless, the simulation of low flow scenario demonstrates that DO concentration was higher than the baseline condition as it reached the fifth reach at $\mathrm{km}$ 65.15. This is due to lower input of $\mathrm{BOD}_{5}$ at the same $\mathrm{km}$ hence decreasing the oxygen consumption. However, the high input of $\mathrm{NH}_{3}-\mathrm{N}$ at $\mathrm{R} 12(\mathrm{~km} \mathrm{19.48)}$ ) of Sungai Langat causes in gradual decrease of oxygen which account for $30 \%$ reduction or $1.03 \pm 0.2 \mathrm{mg} / \mathrm{L}$ (Figure 7). The low flow scenario exhibits that as the water flows downstream, more oxygen is consumed for decaying of other pollutant particularly the high $\mathrm{NH}_{3}-\mathrm{N}$ concentration.

The baseline $\mathrm{BOD}_{5}$ concentration exhibited varying patterns along Sungai Langat stretch. The BOD 5 concentration was in Class II in the upstream stretch of the river, however, increase rapidly as it flows midstream at $\mathrm{km} 68.84$ where high $\mathrm{BOD}_{5}$ load contributed by tributary R4. Based on field observation, the $\mathrm{BOD}_{5}$ load comes from various sources such as farming and animal husbandry, as well as industrial waste and untreated sewage waste along the river. Nonetheless, BOD concentration was diluted and reach Class III of NWQS at $\mathrm{km} 54.79$ as it receives discharge input from R6 (Sungai

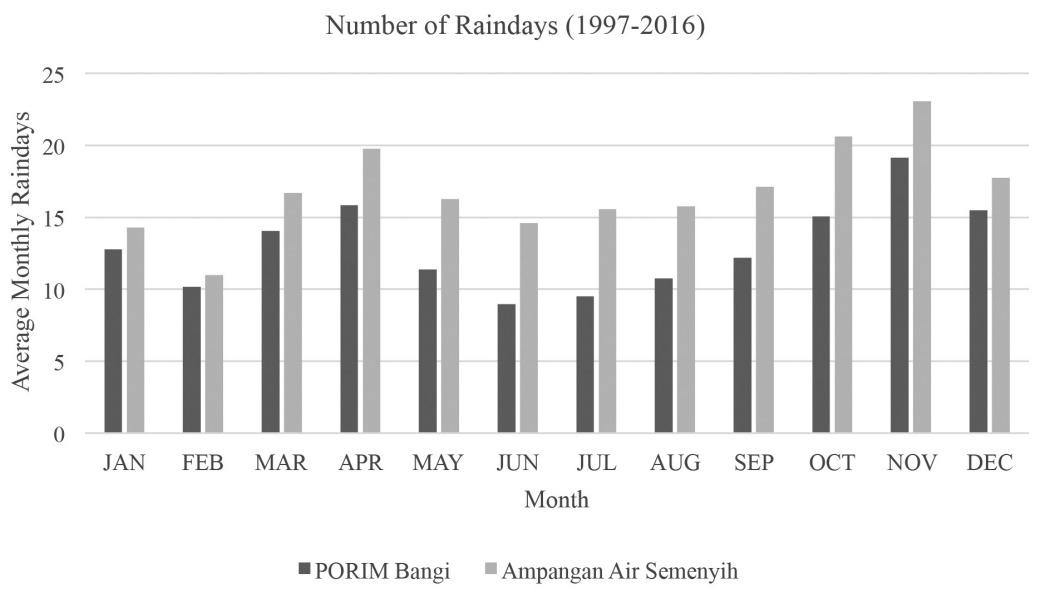

FIGURE 3. 20 years average monthly rain days at PORIM Bangi and Ampangan Air Semenyih Meteorological Station (1997-2016)

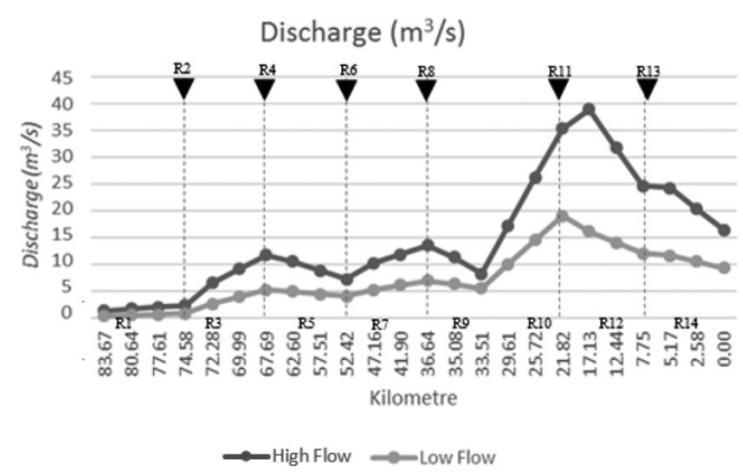

(a)

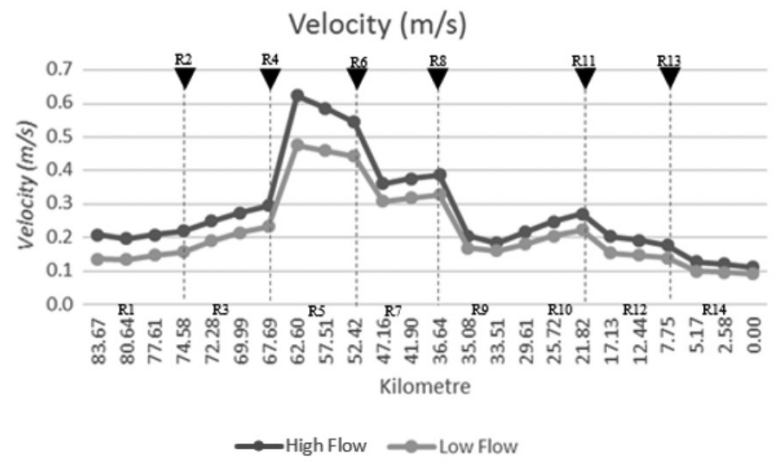

(b)

FIGURE 4. (a) Discharge $\left(\mathrm{m}^{3} / \mathrm{s}\right)$ measurement at Sungai Langat and low flow scenario $\mathrm{Q}_{7,100}$ and

(b) Velocity $(\mathrm{m} / \mathrm{s})$ of high and low flow scenario $\mathrm{Q}_{7,100}$ 
Balak). High $\mathrm{BOD}_{5}$ input at km 36.64 (R9) once again increased the concentration of $\mathrm{BOD}_{5}$ in Sungai Langat and gradually reduced after $\mathrm{km} 34.29$ (R10). The low flow scenario exhibits an improving pattern of $\mathrm{BOD}_{5}$. In this study, $\mathrm{BOD}_{5}$ value decreased due to denitrification as high NH3-N was recorded (5) and (6).

Sungai Langat was known been polluted with $\mathrm{NH}_{3}-\mathrm{N}$ due to organic pollution. The simulation exhibit Sungai Langat between Class II and Class III within the upstream of the river with concentration of $0.42 \pm 0.2 \mathrm{mg} / \mathrm{L}$ (Figure 7 ). The results indicated that $\mathrm{NH}_{3}-\mathrm{N}$ concentration rose significantly after it received water from the tributary at $\mathrm{km} 67.69$ (Class V) where the R4 is introduced. The spike of $\mathrm{NH}_{3}-\mathrm{N}$ concentration is expected from farming and husbandry activities from along the river. Zainudin and Mohamed (2006) reported that Sungai Langat basin received significant amount of sewage at the upstream and downstream of river stretch. The $\mathrm{NH}_{3}-\mathrm{N}$ concentration displayed recovery at $\mathrm{R} 12$ upon receive discharge from $\mathrm{R} 11$, but yet remained in class IV $(2.41 \pm 0.3 \mathrm{mg} / \mathrm{L})$. The low flow scenario exhibited the same pattern of $\mathrm{NH}_{3}-\mathrm{N}$ concentration but increased further at $\mathrm{km} \mathrm{21.82.}$ The simulated $\mathrm{NH}_{3}-\mathrm{N}$ exhibit increment towards to the downstream. Based on field observation, the land use surrounding from $\mathrm{km} 21.82$ to the end of simulation distance is dominated by agricultural activity mainly palm oil plantation. Therefore, simulated $\mathrm{NH}_{3}-\mathrm{N}$ is in line with study conducted by Zainudin et al. (2010) which reported high concentration of $\mathrm{NH}_{3}-\mathrm{N}$ in the river contributed significantly by palm oil plantation. Higher concentration of $\mathrm{NH}_{3}-\mathrm{N}$ at the downstream of Sungai Langat during low flow seemed to consume more DO as part of nitrification.

In the baseline condition, TSS was found to be in class I (12.9 $\pm 4 \mathrm{mg} / \mathrm{L}$ ) along the Sungai Langat stretch (Figure 8).

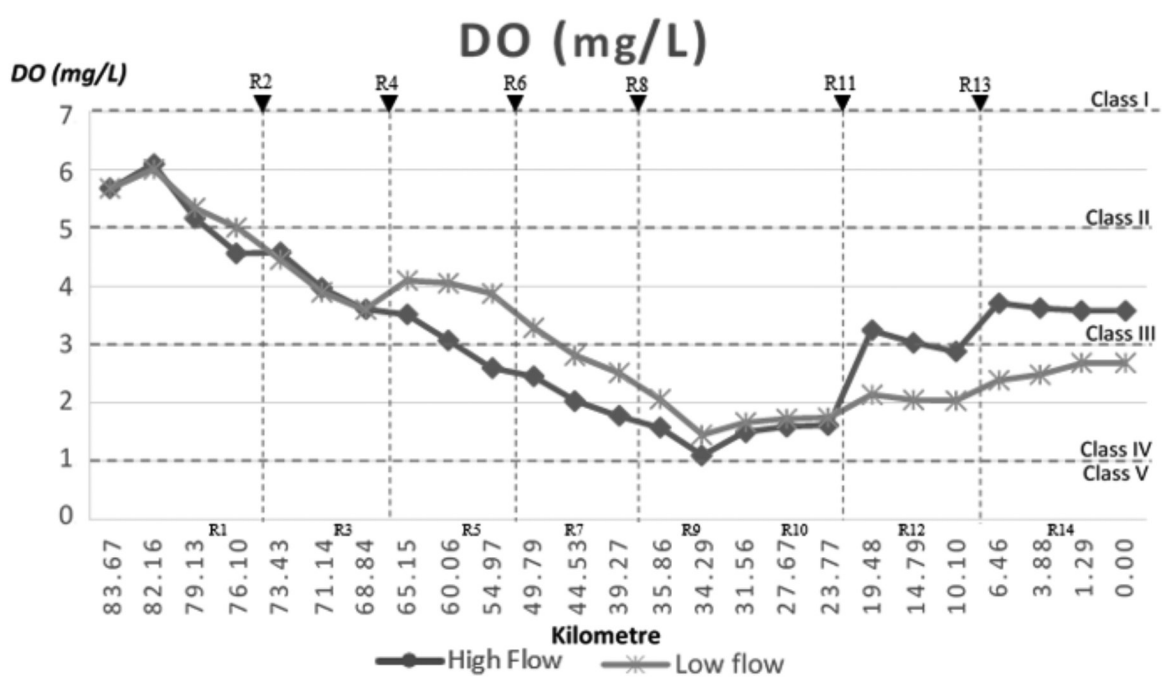

FIGURE 5. Dissolved oxygen (DO) (mg/L) concentration pattern along Sungai Langat

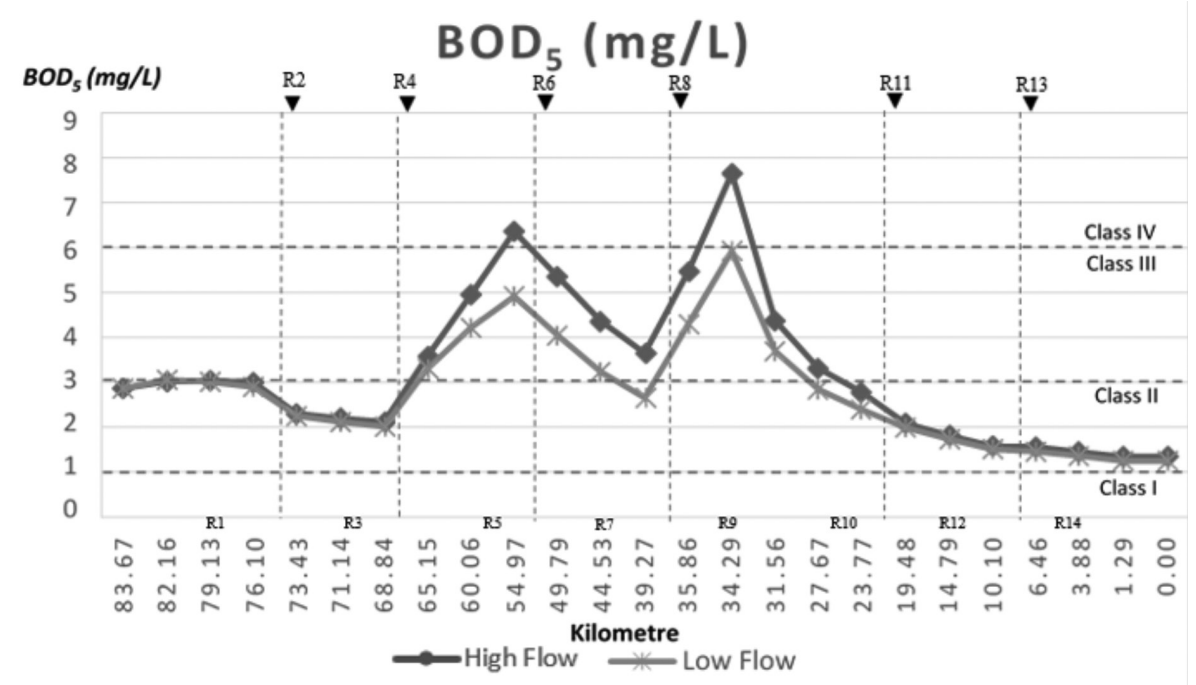

FIGURE 6. Biochemical oxygen demand $\left(\mathrm{BOD}_{5}\right)(\mathrm{mg} / \mathrm{L})$ concentration at Sungai Langat 


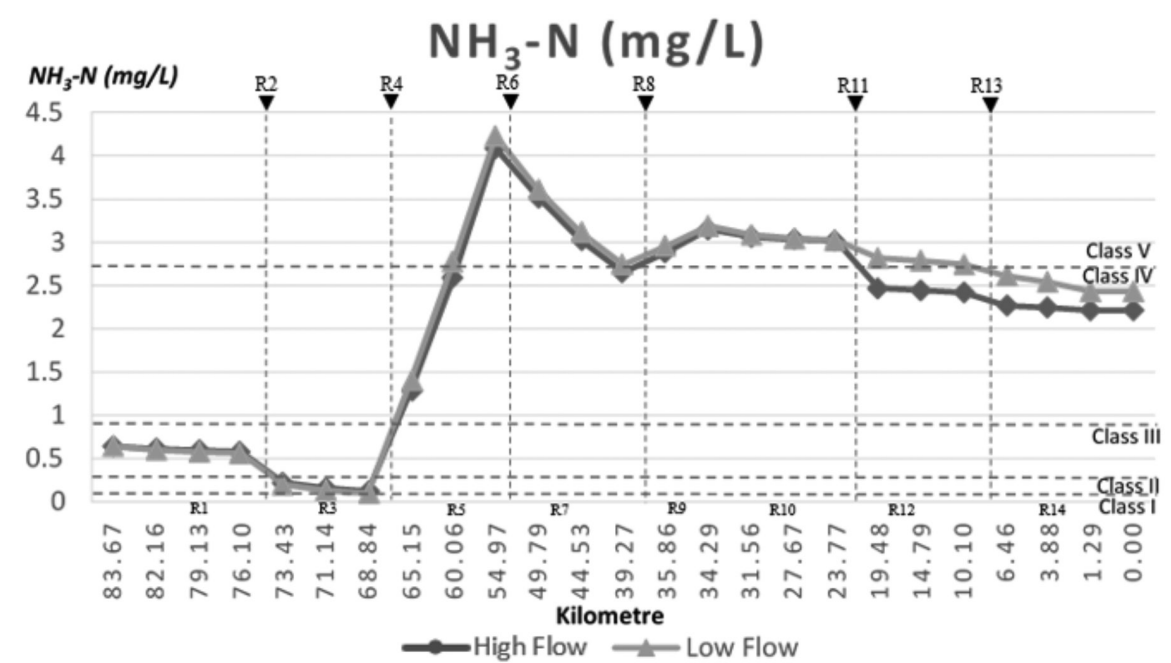

FIGURE 7. Ammonia nitrogen $\left(\mathrm{NH}_{3}-\mathrm{N}\right)(\mathrm{mg} / \mathrm{L})$ concentration along Sungai Langat

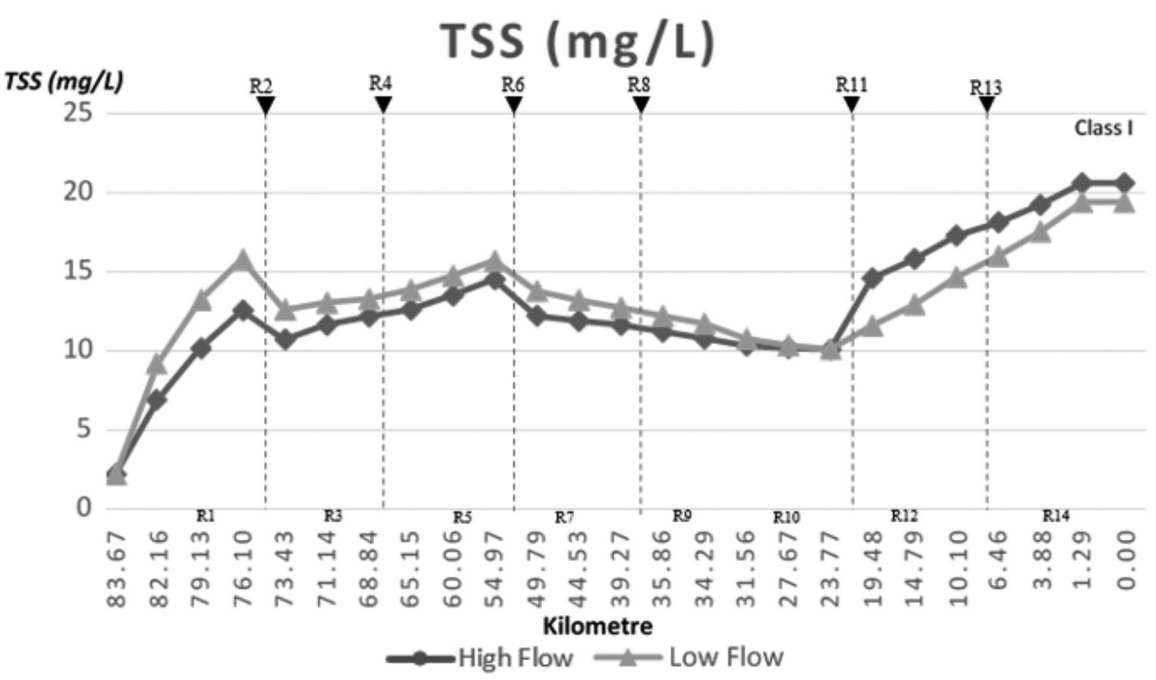

FIGURE 8. Total suspended solids (TSS) (mg/L) concentration along Sungai Langat

However, the concentration of TSS level increased towards the downstream. Inputs from sand mining activities worsened the river TSS level at $\mathrm{km} 21.82$ (R12) but the large waterbody of the river was still able to assimilate the TSS inputs. Nonetheless, the low flow condition exhibits higher concentration level in the upstream area towards the middle stream area. During the dry season, Sungai Langat water body assimilated TSS level for recovery at $\mathrm{km} 21.82$ which caused the TSS level to be lower than baseline. This is due to low rainfall precipitation that causes scarcer soil erosion and sedimentation to flow into the river. Correspondingly, in the wet season, soil erosion increases the TSS concentration (Lai et al. 2013).

\section{CONCLUSION}

It can be concluded that, upstream of Sungai Langat has better water quality compared to middle and downstream.
The simulation shows that during low flow scenario $\left(Q_{7100}\right)$, $\mathrm{NH}_{3}-\mathrm{N}$ gradually increase towards downstream and as nitrification process occurred, DO and BOD were found decreased as ammonia increased. However, the TSS does not show any significant variation in terms of concentration between simulated low flow and actual measurement during high flow. It is clearly shown only TSS has significance on DO saturation, where both have negative correlation. Although some variation was observed between low flow and high flow in Sungai Langat system, it shows that the assimilation capacity is not significantly differ between both scenario. This could be lesser input during the low flow and high load of contaminants during high flow is recovered by large water body discharge.

\section{ACKNOWLEDGEMENTS}

The authors would like to thank Universiti Kebangsaan Malaysia for its facilities and all the support given in 
conducting this study. The author also would like to take this opportunity to thank the Department of Agriculture (DOA) and Department of Meteorology, Malaysia for the secondary data used in this study. Lastly, the author would like to extend appreciation to the staff members at Faculty of Science and Technology for their assistance in completion of the ground data collection.

\section{REFERENCES}

Anon. 2009a. September 29. Salak Tinggi water treatment plant shuts - Nation. The Star Online. https://www.thestar.com. my/news/nation/2009/09/29/salak-tinggi-water-treatmentplant-shuts/.

Anon. 2009b. October 29. Salak Tinggi water plant closed again - Nation. The Star Online. Kuala Lumpur, Malaysia. https:// www.thestar.com.my/news/nation/2009/10/29/salak-tinggiwater-plant-closed-again/.

APHA. 1998. Standard Methods for the Examination of Water and Wastewater. 20th ed. Washington: American Public Health Association.

Chapra, S., Pelletier, G. \& Tao, H. 2008. QUAL2K: A Modeling Framework for Simulating River and Stream Water Quality, Version 2.11: Documentation and Users Manual. Civil and Environmental Engineering Department, Tufts University, Medford, MA.

Choong, M.Z. 2014, February 13. Ammonia contamination at two plants cause of dry taps - Community. The Star Online. Selangor, Malaysia. https://www.thestar.com.my/news/ community/2014/02/13/water-woes-for-residents-ammoniacontamination-at-two-plants-cause-of-dry-taps/.

Chow, V., Maidment, D.R. \& Mays, L.W. 1998. Applied Hydrology. New York: McGraw-Hill. doi:10.1016/j. sonen.2011.11.001

Cubillo, F., Rodriguez, B. \& Barnwell, T.O. 1992. A system for control of river water quality for the community of Madrid using QUAL2E. Water Science and Technology 26: 18671873.

Department of Irrigation \& Drainage. 2011. National Water Resources Study (NRWS) (2000-2050) and Formulation of National Water Resources Policy. Department of Irrigation \& Drainage.

Drolc, A. \& Končan, J.Z. 1996. Water quality modelling of the river Sava, Slovenia. Water Research 30: 2587-2592.

$\mathrm{HACH}$. 2003. The Handbook of DR/2500 Laboratory Spectrophotometer. USA: HACH Company.

Juahir, H., Zain, S.M., Yusoff, M.K., Hanidza, T.I.T., Armi, A.S.M., Toriman, M.E. \& Mokhtar, M. 2011. Spatial water quality assessment of Langat River Basin (Malaysia) using environmetric techniques. Environmental Monitoring and Assessment 173(1-4): 625-641.

Krishnan, G. 2009. Water treatment plants still closed Community The Star Online. Selangor, Malaysia. https:// www.thestar.com.my/news/community/2009/07/24/watertreatment-plants-still-closed/. July 24.

Lai, Y.C., Tu, Y.T., Yang, C.P., Surampalli, R.Y. \& Kao, C.M. 2013. Development of a water quality modeling system for river pollution index and suspended solid loading evaluation. Journal of Hydrology 478: 89-101 . doi:10.1016/j. jhydrol.2012.11.050.
Little, K.W. \& Williams, R.E. 1992. Least-squares calibration of QUAL2E. Water Environment Research 64: 179-185.

LUAS. 2015. Sungai Langat Basin Management Plan 2015-2020. Selangor, Malaysia.

LUAS. 2011. Sungai Langat State of The River Report 2011. Selangor, Malaysia.

Neilson, B.T., Hobson, A.J., Vonstackelberg, N., Shupryt, M. \& Ostermiller, J. 2012. Using Qual2K Modeling to Support Nutrient Criteria Development and Wasteload Analyses in Utah. https://deq.utah.gov/ProgramsServices/ programs/water/wqmanagement/docs/2012/12Dec/ UtahQ2kModelingDataGuidance-Final_12-12-12.pdf.

Ning, S.K., Chang, N.B., Yang, L., Chen, H.W. \& Hsu, H.Y. 2001. Assessing pollution prevention program by QUAL2E simulation analysis for the Kao-Ping River Basin, Taiwan. Journal of Environmental Management 61(1): 61-76.

Othman, J. 2007. Kajian kesan perubahan guna tanah terhadap sumber air Lembangan $\mathrm{Sg}$. Langat melalui integrasi data penderiaan jauh satelit dan GIS serta pemodelan hidrologi. Tesis Dr. Falsafah, Jabatan Kejuruteraan Awam dan Struktur, Universiti Kebangsaan Malaysia (Unpublished).

Puncak Niaga. 2014. Laporan Rondaan Pemantauan Sungai Langat (River Monitoring Work), Empangan Sungai Langat.

Rajendra, E., Lai, A. \& Foo, N. 2016, November 8. Factories along Sungai Langat and Sungai Semantan caused water treatment plants to shut down. The Star Online. Selangor, Malaysia. https://www.thestar.com.my/metro/community/2016/11/08/ sixteen-cases-of-river-pollution-factories-along-sungai-langatand-sungai-semantan-caused-water-trea/

Simmons, D.L. \& Reynolds, R.J. 1982. Effects of urbanization on base flow of selected south-shore streams, Long Island, New York. Journal of the American Water Resources Association 18(5): 797-805.

Song, T. \& Kim, K. 2009. Development of a water quality loading index based on water quality modeling. Journal of Environmental Management 90(3): 3183.

Walton, R. \& Webb, M. 1994. QUAL2E simulations of pulse loads. Journal of Environmental Engineering 120: 1017-1031.

Yang, H.H., Jaafar, O., El-shafie, A. \& Abdullah, S.M.S. 2011. Impact of land-use changes toward base-flow regime in Lui and Langat Dengkil sub-basin. International Journal of the Physical Sciences 6(21): 4960-4976.

Zainudin,Z.,Abdullah, N. \& Mazlan, N.F. 2008. Sewage pollution impact and characterization in $\mathrm{Sg}$. Langat river basin trough QUAL2E river water quality modeling temporal data review. International Conference and Expo on Environmental Management and Technologies (ICEEMAT'08), Putra World Trade Center (PWTC), Kuala Lumpur.

Zainudin, Z. \& Mohamed, M. 2006. Industrial effluent load characterization of Sungai Perembi watershed. Simposium Kimia Analisis Malaysia (SKAM- $\square$ 19), Reviera Beach Resort, Melaka.

Zainudin, Z., Rahman, N.A., Abdullah, N. \& Mazlan, N.F. 2010. Development of water quality model for Sungai Tebrau using QUAL2K. Journal of Applied Sciences 10(21): 2748-2750.

Zhang, R., Qian, X., Yuan, X., Ye, R., Xia, B. \& Wang, Y. 2012. Simulation of water environmental capacity and pollution load reduction using QUAL2K for water environmental management. International Journal of Environmental Research and Public Health 9(12): 4504-4521. 
Zhang, Y.K. \& Schilling, K.E. 2006. Increasing streamflow and baseflow in Mississippi River since the 1940s: Effect of land use change. Journal of Hydrology 324(1-4): 412-422.

School of Environmental Science and Natural Resources Faculty of Science and Technology Universiti Kebangsaan Malaysia 43600 UKM Bangi, Selangor Darul Ehsan Malaysia
*Corresponding author; email: abas@ukm.edu.my

Received: 15 September 2017

Accepted: 20 February 2018 